\title{
Population dynamics of Meloidogyne incognita on cucumber grafted onto the Cucurbita hybrid RS841 or ungrafted and yield losses under protected cultivation
}

Ariadna Giné, ${ }^{1}$

Cristina González, 1

Lydia Serrano, 1

Francisco Javier Sorribas, $1, *$

Email francesc.xavier.sorribas@upc.edu

1 Departament d'Enginyeria Agroalimentària i Biotecnologia AQ1

, Universitat Politècnica de Catalunya, Esteve Terradas 8, 08860 Castelldefels, Barcelona, Spain

\section{Abstract}

The influence of the squash hybrid RS841 rootstock (Cucurbita maxima $\mathrm{x}$ C. moschata) on population dynamics of Meloidogyne incognita and yield of cucumber cv. Dasher II was assessed during 2013 and 2014 in a plastic greenhouse. In addition, the relationship between ecophysiological parameters (plant water status, gas exchange, and leaf reflectance) and $P i$ and cucumber yield were also estimated in 2013. Nematode densities were determined at the beginning $(P i)$ and at the end $(P f)$ of each crop, and the relationship between these parameters was used to estimate the maximum multiplication rate $(a)$, the maximum population density $(M)$ and the equilibrium density $(E)$ per grafted and ungrafted cucumber and cropping season. Moreover, the relationship between the multiplication rate $(P f / P i)$ and $P i$ was compared between grafted and ungrafted cucumber per cropping season. Finally, the relative yield of grafted or ungrafted 
cucumber was plotted against $P i$ to determine the tolerance limit $(T)$ and the minimum relative yield $(m)$ by the Seinhorst damage function model. Values of $a, M$ and $E$ in grafted cucumber were higher than in ungrafted one irrespective of the cropping season. These results were supported by comparing the relationship between $P f / P i$ and $P i$ between grafted and ungrafted cucumber. The relationship between $P i$ and yield fitted the Seinhorst damage function. The values of $T$ and $m$ did not differ between grafted and ungrafted each year. Predawn water potential, net photosynthetic rate, and leaf chlorophyll index decreased with increasing $P i$. In addition, relative yield was related to variation in net photosynthetic rate and the leaf chlorophyll index. Under the conditions of this study, RS841 rootstock was neither resistant nor tolerant to $M$. incognita.

\section{Keywords}

Cucumis sativus

Cucurbita maxima X Cucurbita moschata

Equilibrium density

Multiplication rate

Root-knot nematode

Tolerance limit

\section{Introduction}

Cucumber (Cucumis sativus L.) is one of the most important vegetable crops worldwide, producing 65 million tons per year (FAOSTAT 2016). Spain produces 748,500 tons of cucumbers per year in 8811 ha, of which, $88 \%$ are under protected cultivation (MAGRAMA 2013). Cucumber is susceptible-intolerant to the most common root-knot nematodes (RKN) species, which can cause yield losses up to $88 \%$ under protected cultivation (Giné et al. 2014). Despite the chemical control is the most used control method (Talavera et al. 2012), non-chemical alternatives are needed in order to implement the European Directive 2009/128/EC.

Grafting is one of the most promising horticultural techniques, which involves the union of the aerial part (scion) of a susceptible plant with a root system (rootstock) of a resistant one. The main purpose of this technique is to control plant pathogens causing soil-borne diseases, including plant parasitic nematodes, to enhance tolerance to abiotic stresses, and to improve 
yield (Edelstien 2004; Davis et al. 2008; King et al. 2010; Lee and Oda 2010; Lee et al. 2010). Several cucurbit rootstocks have been tested against RKN (Sigüenza et al. 2005; Davis et al. 2008; Lee and Oda 2010; KokalisBurelle and Rosskopf 2011; Liu et al. 2015; Thies et al. 2015; LópezGómez et al. 2016). Among them, the squash interspecific hybrid (Cucurbita maxima x C. moschata) is the most widely used rootstock for cucumber, melon and watermelon in Europe (Lee et al. 2010). This rootstock is resistant to Fusarium oxysporum f. sp. melonis, F. oxysporum f. sp. cucumerinum, $F$. oxysporum f. sp. lagenariae, $F$. oxysporum f. sp. niveum, F. oxysporum f. sp. radicis-cucumerinum, Rhizoctonia solani and Verticillium dahliae (Davis et al. 2008; Pavlou et al. 2002; USDA 2015 ). Regarding RKN, the level of resistance reported is not consistent, being either susceptible or resistant (Davis et al. 2008; Cansev and Ozgur 2010; Kokalis-Burelle and Rosskopf 2011; Goreta Ban et al. 2014; USDA 2015) but no information about its tolerance when cucumber is grafted as a scion is available. In order to know the host status of the rootstock under particular agro-environmental conditions, the relationship between nematode density at planting $(P i)$ and at the end of the crop (Pf) has to be determined to estimate the maximum multiplication rate (in absence of limiting factors) $(a)$, the maximum population density (the maximum $P f$ achieved by a nematode population on a plant host under particular conditions) $(M)$, and the equilibrium density (when the plant can supply enough food to maintain the population density at planting; $P f=P i ; P f / P i=1)(E)$ (Seinhorst 1967). These parameters are higher on susceptible hosts than on resistant or poor hosts. Another useful indicator of the population growth rate is the relationship between the multiplication rate $(P f / P i)$ and $P i$. It allows comparing nematode population dynamics on different plant species or germplasms or between cropping seasons for a given pathosystem and the efficacy of control methods (Talavera et al. 2009; Vela et al. 2014). Those parameters refer to nematode population growth but do not provide valuable information on marketable crop yield, which is provided by the relationship between $P i$ and relative crop yield by the Seinhorst damage function model, the tolerance limit and the minimum relative yield (Seinhorst 1965). It is known that plant growth and yield are reduced at increasing $P i$ above the tolerance limit due to a reduction of water and nutrient intakes, and consequently, a reduction of plant conductivity and transpiration, as well as leaf chlorophyll content and photosynthesis rate (Loveys and Bird 1973; Melakeberhan 2003; Agrios 2005; Strajnar et al. 2012). Leaf chlorophyll content, photosynthesis rate, and plant biomass have previously been related 
to $\mathrm{Pi}$ (Melakeberhan et al. 1985; Giné et al. 2014; López-Gómez et al. 2015 ). Therefore, these ecophysiological parameters might be potential indicators of tolerance and yield losses, but it needs to be evaluated under field conditions.

The aim of this study was to determine the influence of the rootstock RS841 (Cucurbita maxima x C. moschata) on the population dynamics of the RKN, Meloidogyne incognita and yield of cucumber cv. Dasher II cultivated in a plastic greenhouse during two cropping seasons. In addition, the relationship between several ecophysiological parameters and $P i$ and cucumber yield was also assessed.

\section{Materials and methods}

Experiments were carried out in spring 2013 and 2014 in a $700 \mathrm{~m}^{2}$ plastic greenhouse located at Viladecans (Barcelona, Spain) which had been artificially infested with $M$. incognita in 2007 . The soil texture was sandy loam with $83.8 \%$ sand, $6.7 \%$ loam and $9.5 \%$ clay; $\mathrm{pH} 8.7 ; 1.8 \%$ organic matter $(w / w)$, and $0.5 \mathrm{dS} \mathrm{m}^{-1}$ electrical conductivity. From 2007 until the beginning of the experiments, rotations with resistant or susceptible tomato cultivars and cucumber or fallow were done.

Forty-four gross plots of $9.6 \mathrm{~m}^{2}$ were cultivated with each of grafted or ungrafted cucumber. Individual gross plots consisted of 24 plants spaced $50 \mathrm{~cm}$ within each of four rows and $55 \mathrm{~cm}$ between rows which is the normal plant density applied by growers in greenhouse (Ornat et al. 1997). Net plots of $3.2 \mathrm{~m}^{2}$ comprised the central part of the plot in which eight plants were cropped and from which soil and roots samples were taken and crop yield was assessed. The soil of each plot was prepared individually to prevent cross contamination. In 2013, the cucumber crop was preceded by resistant or susceptible tomato cultivars or fallow to achieve gradients of nematode densities. In 2014, the cucumber crop was preceded by fallow. Cucumber cv. Dasher II was grafted onto Cucurbita maxima x C. moschata hybrid RS841 by tongue approach, because it is easy to apply, successful, and provides a uniform growth rate (Davis et al. 2008). The squash hybrid RS841 has been proven to develop a longer root system than cucumber and to improve crop yield (Maršić and Jakše 2010). Grafted and ungrafted cucumber was cropped from April 14th to July 16th in 2013 (78 days) and in 2014 from March 3rd to June 19th (109 days) which is the normal period of cultivating commercially in greenhouse in the growing area of the study 
(Giné et al. 2016). Plants were irrigated as needed through a drip irrigation system and weekly fertilized with a solution consisting of NPK (15-5-30) at $31 \mathrm{~kg} \mathrm{ha}^{-1}$ and iron chelate and micronutrients at $0.9 \mathrm{~kg} \mathrm{ha}^{-1}$. Cucumber plants were vertically trained. Weeds were removed manually during and between crops. Fruits from the eight central plants of each plot were harvested when they reached the standard commercial size and were expressed as $\mathrm{kg}$ per $\mathrm{m}^{2}$. Soil temperatures were recorded daily at $30 \mathrm{~min}$ intervals with temperature probes 5TM (Decagon devices, Inc) placed at a soil depth of $15 \mathrm{~cm}$.

At the end of the cropping season, plants were removed from the ground with a pitchfork. Disease severity was rated by Zeck's scale from 0 to 10 (Zeck 1971), where $0=$ complete and healthy root system and $10=$ plants and roots dead. After that, eggs were extracted from two root subsamples of $20 \mathrm{~g}$ by maceration in a blender containing a $1 \% \mathrm{NaOCl}$ solution for $10 \mathrm{~min}$ (Hussey and Barker 1973). The suspension was sieved through a $74 \mu \mathrm{m}$ aperture screen, to remove root debris, and through a $25 \mu \mathrm{m}$ aperture screen to retain the eggs. The number of eggs were counted and expressed per gram of root.

Second-stage juveniles $\left(\mathrm{J}_{2}\right)$ in soil were estimated at the beginning (initial population, $P i$ ) and at the end (final population, $P f$ ) of each crop. Soil samples were taken from each of the forty-four net plots. Composite soil samples consisted of eight soil cores taken from the first $30 \mathrm{~cm}$ of soil with a soil auger of $2.5 \mathrm{~cm}$ diameter. Soil samples of about $1.2 \mathrm{~L}$ were homogenized and sieved through a $4 \mathrm{~mm}$ aperture screen to remove stones and separate roots from the soil. $\mathrm{J}_{2}$ were extracted from a $500 \mathrm{~cm}^{3}$ of soil subsample using Baermann trays (Whitehead and Hemming 1965) incubated at $27^{\circ} \mathrm{C}$ for a week. The efficiency to recover nematodes from soil by Baermann trays was $43 \% . \mathrm{J}_{2}$ in soil that migrated to the water were then collected sieving the suspension thorough a $25 \mu \mathrm{m}$ aperture screen. The roots recovered from the $4 \mathrm{~mm}$ sieve were weighted and the eggs were extracted as described above (Hussey and Barker 1973). The number of eggs in the whole root system was not included in the $P f$ value as it is usual in microplots and field experiments (Barker et al. 1976; Ferris 1985; Noling and Ferris 1986). Initial population density $(P i)$ is expressed as $J_{2} 250 \mathrm{~cm}^{-3}$ of soil because no roots were found. Final population density $(P f)$ is expressed as $\mathrm{J}_{2}+$ eggs $250 \mathrm{~cm}^{-3}$. The estimation of the maximum multiplication rate $(a)$ was carried out considering the $P f$ at a very low $P i$, 
according to $P f=a P i$ (Seinhorst 1970), and the maximum population density at the end of the crop $(M)$ from the experimental data. The equilibrium density $(E)$ was calculated according to the expression $M=a E$ / (a-1) (Schomaker and Been 2006).

In addition, in 2013, plant water status, gas exchange and leaf reflectance were measured 60 days after transplanting. Measurements were carried out in grafted and ungrafted plants growing in plots with $P i$ ranging from 0 to $765 \mathrm{~J}_{2}+$ eggs $250 \mathrm{~cm}^{-3}$ of soil. Predawn water potential $\left(\Psi_{\mathrm{p}}\right)$ was determined using a Scholander pressure chamber (Soilmoisture 3005, Soil Moisture Corp., Santa Barbara CA, USA) early in the morning (around 7:00 a.m. solar time) on three leaves that were covered with both aluminum foil and plastic bags the night before. Net photosynthetic rate (A), stomatal conductance $\left(\mathrm{g}_{\mathrm{s}}\right)$ and transpiration $(\mathrm{E})$ were measured between 11:00 a.m. and 12:30 p.m. (solar time) with a portable gas exchange system CIRAS-2 (PP Systems Ltd., Havervill MA, USA) in three fully expanded leaves (one leaf/plant). Gas exchange parameters were determined at a $\mathrm{CO}_{2}$ concentration in the cuvette of $400 \mathrm{ppm}$ whereas temperature and water vapor concentration were not controlled. Afterwards, leaf reflectance was determined using a spectroradiometer (Unispec, PP Systems, Ltd., Harvervill, MA, USA) with a $2.3 \mathrm{~mm}$ diameter bifurcated fiber optic (model UNI410, PP Systems, Havervill, MA, USA). The detector samples 256 bands at roughly evenly-spaced intervals (average band-to-band spacing $3.3 \mathrm{~nm}$ ) within a 400-1100 nm effective spectral range. Among several chlorophyll reflectance-based indices tested, the chlorophyll index proposed by Datt (1998) $\left(\mathrm{R}_{672} /\left[\mathrm{R}_{550} \times \mathrm{R}_{708}\right]\right)$ was selected.

\section{Statistical analyses}

Statistical analyses were carried out using the SAS system V9 (SAS Institute Inc., Cary, NC). The values of $P i$ and $P f / P i$ were transformed to $\log 10$ to linearize them and the relationship between $P i$ and $P f / P i$ for grafted or ungrafted cucumber was determined per cropping season by regression analysis (proc reg). The resulting regressions per grafted or ungrafted cucumber between cropping seasons were compared by the general lineal model procedure (proc glm). When no differences $(P<0.05)$ were found, data were pooled to construct a single general model and a new comparison of regression was carried out between grafted and ungrafted cucumber. 
$P i$ values and submitted to a non-linear regression analysis (proc nlin) to determine if they fitted the Seinhorst damage function model $(y=m+(1-m)$ $0.95^{(P i / T-1)}$; when $P i \geq T$, and $y=1$ when $P i<T$, where $y$ is the relative yield (the yield at a given $P i$ divided by the yield at $P i \leq T$, with $y=1$ at $P i \leq T), m$ is the minimum relative yield (the lowest value of the relative yield at higher $P i$ ), and $T$ is the tolerance limit (the nematode density ( $P i$ ) up to which no yield losses occurs). Values of minimum relative yield $(m)$, and tolerance limit $(T)$ were compared between grafted and ungrafted cucumber per cropping season considering confidence intervals at 95\% (Giné et al. 2014).

Correlation analysis (proc corr) was used to determine the relationship among ecophysiological parameters $\left(\Psi_{\mathrm{p}}, \mathrm{A}\right)$, the chlorophyll reflectance based index $\mathrm{R}_{672} /\left[\mathrm{R}_{550} \times \mathrm{R}_{708}\right]$ and both $P i$ and relative yield on both grafted and ungrafted cucumber plants.

\section{Results}

Absolute soil temperatures ranged from $17.5^{\circ} \mathrm{C}$ and $31.6{ }^{\circ} \mathrm{C}$ in 2013 (accumulated degree days $1946, \mathrm{~Tb}=0{ }^{\circ} \mathrm{C}$ ) and from $17.7^{\circ} \mathrm{C}$ to $28.8{ }^{\circ} \mathrm{C}$ in 2014 (accumulated degree days $2546, T b=0{ }^{\circ} \mathrm{C}$ ). The nematode was able to complete two generations in both cropping seasons according to its thermal requirements $\left(\mathrm{Tb}=11.4{ }^{\circ} \mathrm{C}\right.$ and thermal constant $=500$ degree days over Tb; Giné et al. 2014).

In 2013, $P i$ ranged from 0 to $6180 \mathrm{~J}_{2} 250 \mathrm{~cm}^{-3}$ of soil in plots cultivated with grafted cucumber, and from 0 to $894 \mathrm{~J}_{2} 250 \mathrm{~cm}^{-3}$ of soil in those cultivated with the ungrafted one. In 2014, $P i$ ranged from 0 to $220 \mathrm{~J}_{2}$ $250 \mathrm{~cm}^{-3}$ of soil in plots cultivated with either grafted or ungrafted cucumber.

The maximum multiplication rate $(a)$, the maximum population density $(M)$ and the equilibrium density $(E)$ on grafted cucumber in 2013 were $11,846,23,257,23,255 \mathrm{~J}_{2}+$ eggs $250 \mathrm{~cm}^{-3}$ of soil, respectively, and 1004, 9918 and $9909 \mathrm{~J}_{2}+$ eggs $250 \mathrm{~cm}^{-3}$ of soil, respectively in the ungrafted one (Fig. 1). In 2014, $a, M$ and $E$ on grafted cucumber were 9270, 13,067 and $13,066 \mathrm{~J}_{2}+$ eggs $250 \mathrm{~cm}^{-3}$ of soil, respectively, and in the ungrafted cucumber were 2323,4272 , and $4270 \mathrm{~J}_{2}+$ eggs $250 \mathrm{~cm}^{-3}$ of soil, respectively (Fig. 1). The relationship between $P i$ and $P f / P i$ on grafted or 
ungrafted cucumber did not differ between cropping seasons (in grafted: intercept $P=0.7232$ and slope $P=0.5347$; in ungrafted: intercept $P=0.0782$ and slope $P=0.0907)$, but it did when comparison was carried out between grafted and ungrafted cucumber with pooled data (intercept $P=0.0037$ and slope $P=0.0884$ ) (Fig. 2). Meloidogyne incognita produced more $(P<0.05)$ eggs per gram of root, and less $(P<0.05)$ galling index on the grafted than ungrafted cucumber in both cropping seasons (Table 1). Grafted cucumber had a higher frequency of plants with galling index between 3 and 7 than the ungrafted ones (Fig. 3 ).

\section{Fig. 1}

Relation between final $(P f)$ and initial populaton density $(P i)$ of Meloidogyne incognita on ungrafted cucumber cv. Dasher II and grafted onto the cucurbit hybrid RS841 (Cucurbita maxima x C. moschata) in 2013 and 2014. The numbers of observations were 17 and 20 of rootstock RS841 in 2013 and 2014 respectively, and 20 in cucumber cv. Dasher II for both years. Numbers of observations of each point are in the table inside the figure 

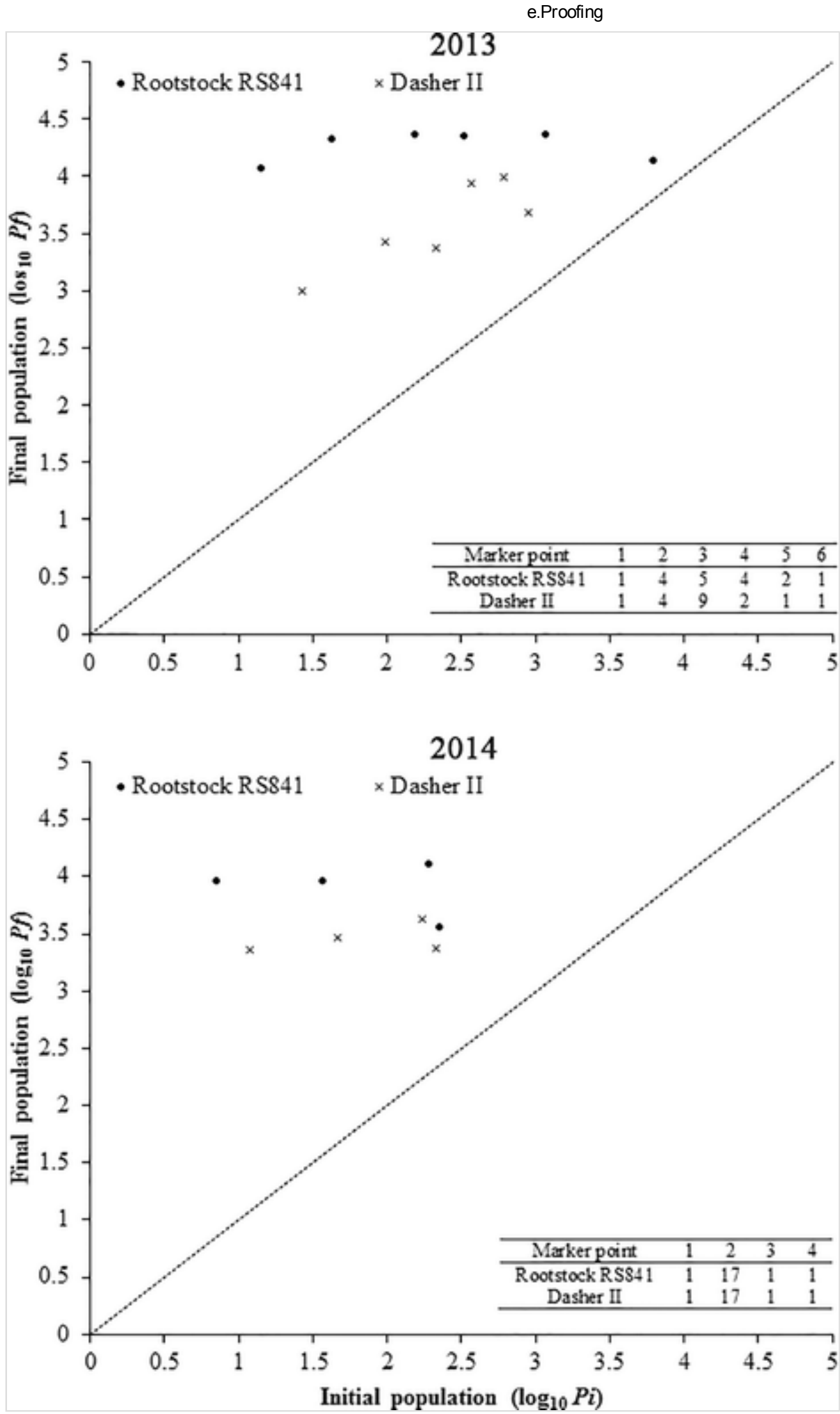

\section{Fig. 2}

General model of the relationship between initial population density $(P i)$ and multiplication rate $(P f / P i)$ of Meloidogyne incognita on ungrafted cucumber cv. Dasher II and grafted onto the cucurbit hybrid RS841 (Cucurbita maxima x C. moschata) cropped in plastic greenhouse from April to July in 2013 and from March to June in 2014. The numbers of observations were 17 and 20 of 
rootstock RS841 in 2013 and 2014 respectively, and 20 in cucumber cv. Dasher II for both years. Numbers of observations of each point are the same than Fig. 1

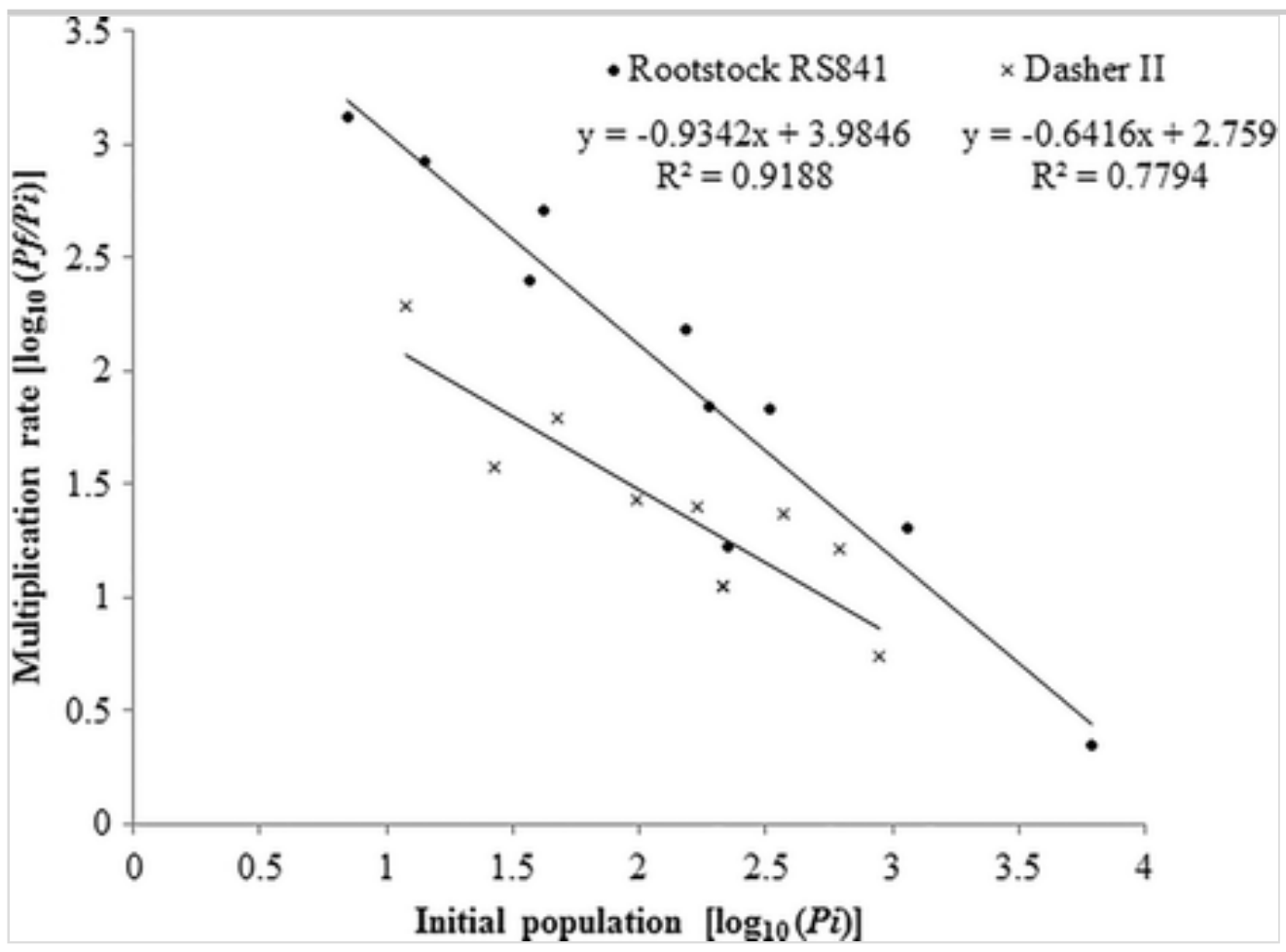

\section{Table 1}

Number of eggs of Meloidogyne incognita per gram of root and galling index on ungrafted cucumber cv. Dasher II and grafted onto the cucurbit hybrid RS841 (Cucurbita maxima x C. moschata) in 2013 and 2014

\begin{tabular}{|c|c|c|c|}
\hline Year & Treatment & Eggs per g root & Galling inde $x^{a}$ \\
\hline \multirow{2}{*}{2013} & Rootstock RS841 & $19,054 \pm 2591^{*}$ & $7.4 \pm 0.21 *$ \\
\hline & Dasher II & $3822 \pm 788$ & $8.5 \pm 0.21$ \\
\hline \multirow{2}{*}{2014} & Rootstock RS841 & $9675 \pm 123^{*}$ & $7.3 \pm 0.25^{*}$ \\
\hline & Dasher II & $4490 \pm 551$ & $8.1 \pm 0.27$ \\
\hline \multicolumn{4}{|c|}{$\begin{array}{l}\text { Values are means } \pm \text { standard deviations of } 22 \text { replicated plots in all } \\
\text { treatments. Data within the same column and year followed by *indicates a } \\
\text { significant difference between soil treatment at } P<0.05 \text { according to the } \\
\text { Student's } t \text {-test }\end{array}$} \\
\hline
\end{tabular}

Fig. 3

Desease severity (galling index) of Meloidogyne incognita on ungrafted 
cucumber cv. Dasher II and grafted onto the cucurbit hybrid RS841 (Cucurbita maxima x C. moschata) cropped in plastic greenhouse from April to July in 2013 and from March to June in 2014 in plots with $P i>0$

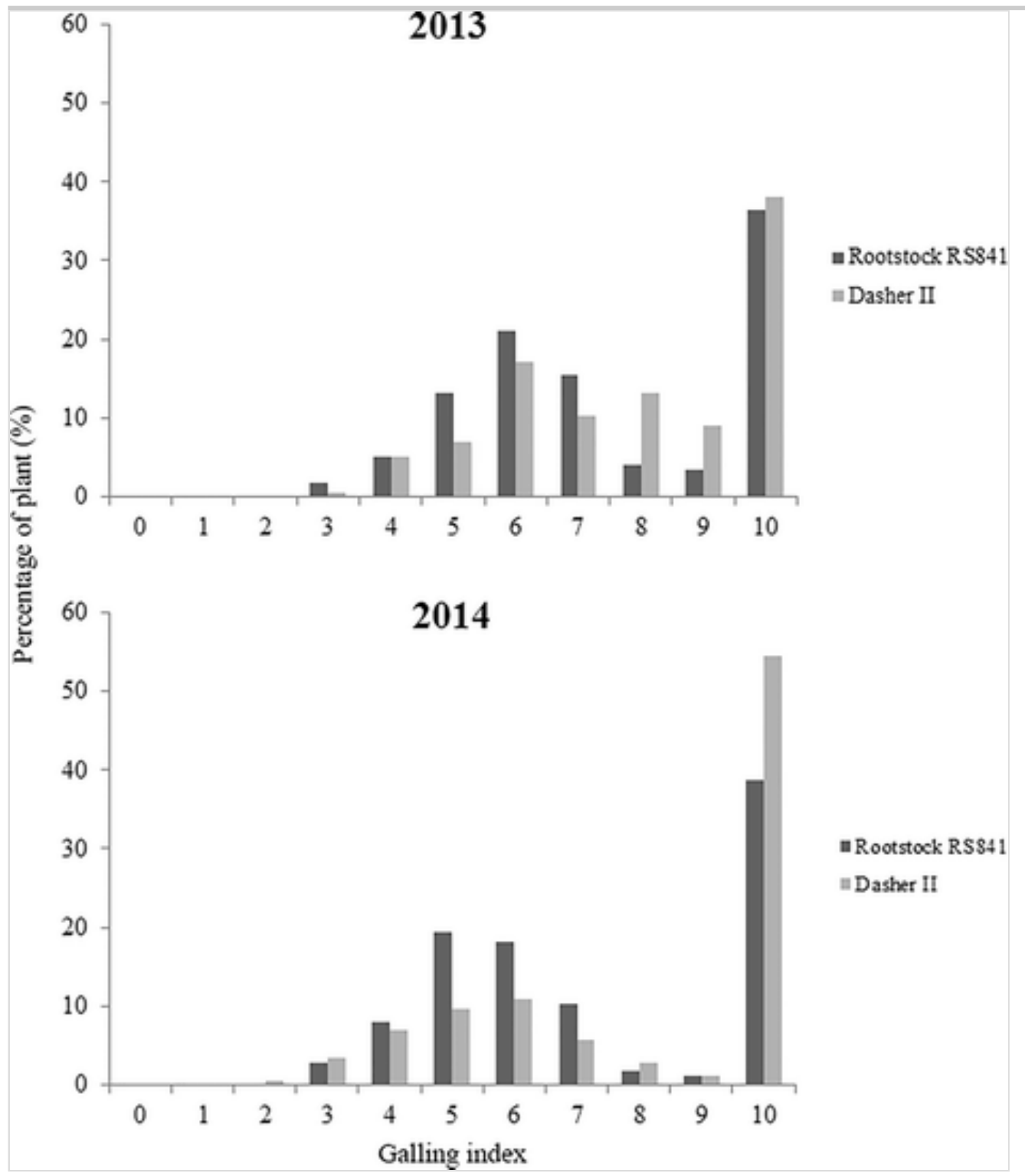

Grafted cucumber yielded 4.2 and $3.7 \mathrm{~kg} \mathrm{~m}^{-2}$ in 2013 and 2014 , respectively, and 5.3 and $3.7 \mathrm{~kg} \mathrm{~m}^{-2}$ the ungrafted one on the nematode free plots. The relationship between $P i$ and grafted or ungrafted relative cucumber yield fitted the Seinhorst damage function model. The tolerance limit and the minimum relative yield of both grafted and ungrafted cucumber did not differ per cropping season (Fig. 4).

Fig. 4

Seinhorst damage function model of Meloidogyne incognita of ungrafted cucumber cv. Dasher II and grafted onto the cucurbit hybrid RS841 (Cucurbita maxima x C. moschata) cropped in plastic greenhouse from April to July in 2013 and from March to June in 2014 


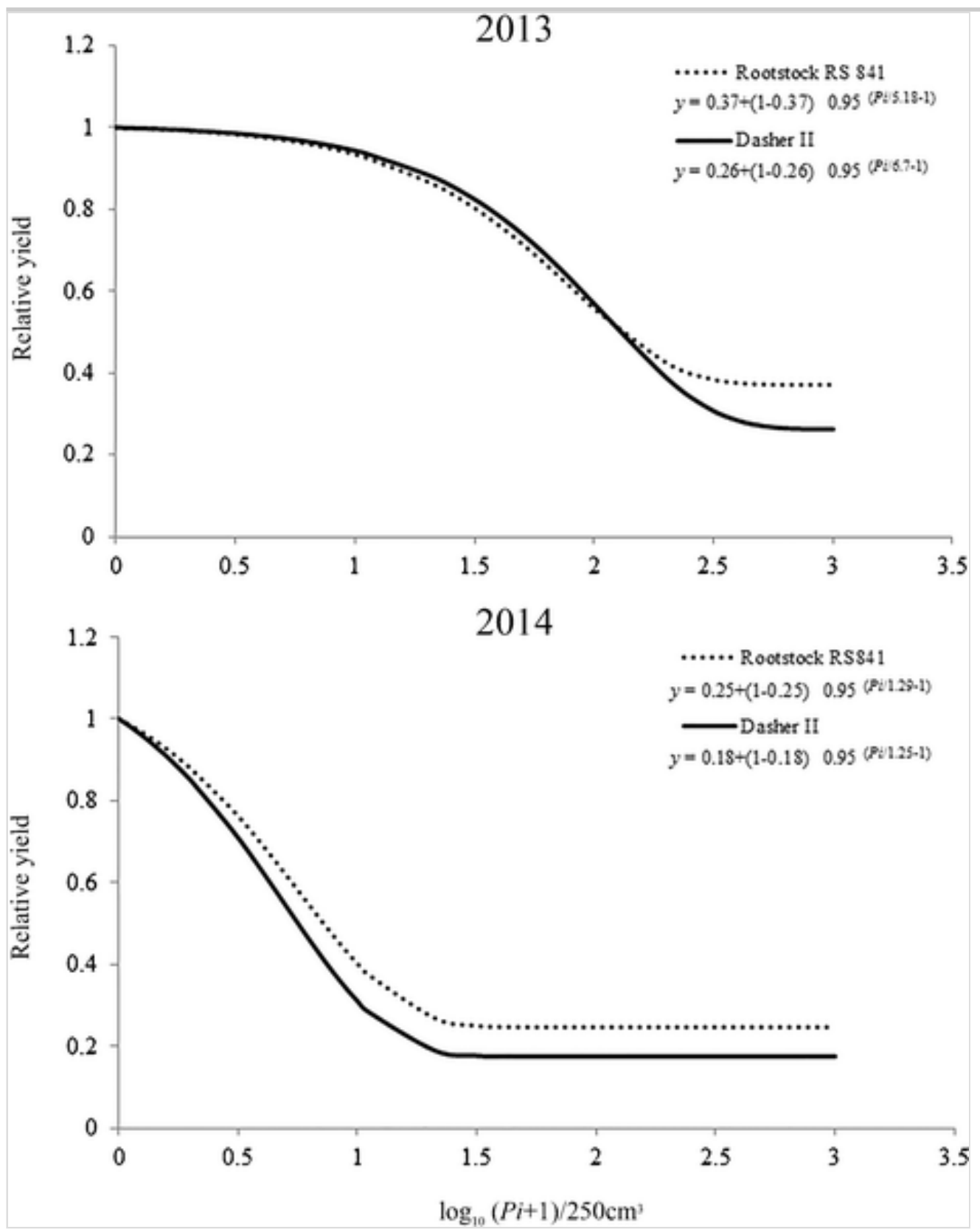

Predawn water potential $\left(\Psi_{\mathrm{p}}\right)$ decreased with increasing $P i(r=-0.76$; $P<0.01)$ for both grafted and ungrafted cucumber, ranging from $-0.38 \pm 0.02 \mathrm{MPa}$ (average \pm standard error) at $P i=0$ to $-0.62 \pm 0.04 \mathrm{MPa}$ at $P i=765$ (Table 2). Similarly, $A$ and $\mathrm{R}_{672} /\left[\mathrm{R}_{550} \times \mathrm{R}_{708}\right]$ (Table 2) showed significant correlation against $P i$ with $r=-0.66(P<0.01)$ and $r=-0.48(P<0.05)$, respectively. Moreover, for both grafted and ungrafted plants, $\Psi_{\mathrm{p}}$ showed significant correlation against net photosynthetic rate (A) $(r=0.53 ; P<0.05)$ and $\mathrm{R}_{672} /\left[\mathrm{R}_{550} \times \mathrm{R}_{708}\right](r=-0.76 ; P<0.01)$. In addition, the relative variation in $\mathrm{R}_{672} /\left[\mathrm{R}_{550} \times \mathrm{R}_{708}\right]$ was found to be significantly related to relative decreases in $\mathrm{A}\left(R^{2}=0.91, P<0.01\right)$. Furthermore, decreases in relative cucumber yield were significantly related to both the relative variation in $\mathrm{A}\left(R^{2}=0.88, P<0.01\right)$ and the relative 
variation in $\mathrm{R}_{672} /\left[\mathrm{R}_{550} \times \mathrm{R}_{708}\right]\left(R^{2}=0.91, P<0.01\right)$.

Table 2

Predawn water potential $\left(\Psi_{\mathrm{p}}\right)$, net photosynthetic rate (A) and chlorophyll index $\left(\mathrm{R}_{672} /\left[\mathrm{R}_{550} \times \mathrm{R}_{708}\right]\right)$ of ungrafted cucumber cv. Dasher II and grafted onto the cucurbit hybrid RS841 (Cucurbita maxima x C. moschata) cultivated in soil infested by increasing Meloidogyne incognita densities at transplanting (Pi)

\begin{tabular}{|c|c|c|c|c|}
\hline Treatment & $\begin{array}{c}P i\left(J_{2} 250 \mathrm{~cm}\right. \\
-3 \text { of soil })\end{array}$ & $\Psi_{p}(\mathrm{MPa})$ & $\begin{array}{c}\mathrm{A} \\
\underset{\left.\mathrm{m}^{-2} \mathrm{~s}^{-1}\right)}{\mu \mathrm{mol} \mathrm{CO}_{2}}\end{array}$ & $\begin{array}{c}\mathbf{R}_{672} /\left[R_{550} x\right. \\
\left.R_{708}\right]\end{array}$ \\
\hline \multirow{3}{*}{$\begin{array}{l}\text { Rootstock } \\
\text { RS841 }\end{array}$} & 0 & $-0.38 \pm 0.02$ & $11.37 \pm 0.86$ & $0.912 \pm 0.052$ \\
\hline & 342 & $-0.47 \pm 0.02$ & $8.60 \pm 2.64$ & $0.827 \pm 0.110$ \\
\hline & 765 & $-0.62 \pm 0.07$ & $4.90 \pm 0.75$ & $0.680 \pm 0.031$ \\
\hline \multirow{3}{*}{ Dasher II } & 0 & $-0.47 \pm 0.02$ & $8.60 \pm 2.17$ & $0.827 \pm 0.093$ \\
\hline & 301 & $-0.47 \pm 0.03$ & $5.57 \pm 4.64$ & $0.578 \pm 0.022$ \\
\hline & 666 & $-0.58 \pm 0.07$ & $1.63 \pm 0.78$ & $0.524 \pm 0.033$ \\
\hline
\end{tabular}

\section{Discussion}

Grafting susceptible crops onto resistant-tolerant rootstocks is a promising non-chemical alternative to manage RKN because nematode population will be suppressed and the crop will suffer less yield losses than cropping susceptible-intolerant cultivars. Several commercial resistant tomato and pepper rootstocks have been shown their effectiveness against RKN (Oka et al. 2004; Ros et al. 2006; Cortada et al. 2008; Verdejo-Lucas and Sorribas 2008; Kokalis-Burelle et al. 2009; Verdejo-Lucas et al. 2009). However, despite the fact that the effectiveness of cucurbit rootstocks against RKN has been studied (Thies et al. 2010; Lee et al. 2010; Liu et al. 2015; Thies et al. 2015; López-Gómez et al. 2016), there are not available resistant commercial rootstocks for cucumber and melon. Nevertheless, some promising results have been reported, such as with Cucumis metuliferus, which has been proven to be highly resistant to root-knot nematodes (Lee et al. 2010; Kokalis-Burelle and Rosskopf 2011; Thies et al. 2012; Picó et al. 2013; Munera et al. 2014) and is compatible with some melon cultivars (Sigüenza et al. 2005; Gisbert et al. 2014; Guan et al. 2014).

Although the squash hybrid rootstock Cucurbita maxima x C. moschata is 
widely used, little information is available about its performance against increasing $P i$ of RKN in terms of host status, crop yield, and ecophysiological parameters. The results of this study showed that RKN population dynamics on ungrafted or grafted cucumber onto RS 841 differed, being the former less good host than the grafted according to $a$, and $E$ values. These parameters are indicators of the host status in a given agroenvironmental conditions (Seinhorst 1967). High values of $a$ and $E$ are indicators of good plant hosts and low values of poor or resistant ones. In this study, $a$ values of $M$. incognita on grafted cucumber were closer between cropping season and around $84 \%$ higher than on the ungrafted one. The $M$ and $E$ values on grafted cucumber were also higher (around 62\%) than in the ungrafted one. These results were also supported by the estimation of the population growth rate on grafted and ungrafted cucumber by the relationship between $P f / P i$ and $P i$. The population growth rate on grafted cucumber was higher than on the ungrafted one. That is, the $a$ value was $94 \%$ higher on grafted than on ungrafted cucumber, however, the $E$ values were similar. These results could be explained because the root system of the rootstock RS841 is larger than that of the cucumber, for example cv Edona F1 (Maršić and Jakše 2010), but as far we know, there is no information comparing the rootstock RS 841root system with that of cucumber cv. Dasher II. Thus, Cucurbita maxima x C. moschata RS481 is not resistant neither poor host to RKN.

The agro-environmental conditions in which the crop is cultivated can play an important role in population dynamics (Seinhorst 1967). The results of this study show that values of $a$ and $E$ of $M$. incognita on ungrafted cucumber cv. Dasher II cropped in spring-summer (April to July) were lower than those reported by Giné et al. (2014) when cucumber was cropped in summer-autumn (July to November). Similar results were reported for $M$. incognita on zucchini-squash (Vela et al. 2014) and for M. artiellia on chickpea (Di Vito and Greco 1988).

The relationship between $P i$ and relative yield of both grafted and ungrafted cucumber fitted the Seinhorst damage function model. The tolerance limit did not differ between cropping season. Estimated values of $T$ were between 1 and $7 \mathrm{~J}_{2} 250 \mathrm{~cm}^{-3}$ of soil, being similar to those reported for grafted melon onto the squash hybrid Shintozoa (Kim and Ferris 2002) or ungrafted melon (Ploeg and Phillips 2001), but higherlower than for watermelon (50 $\mathrm{J}_{2}$ $250 \mathrm{~cm}^{-3}$ of soil) (López-Gómez et al. 2014). Cucumber yield losses ranged 
from 63 to $83 \%$ irrespective of grafting, similar to those reported for ungrafted or grafted melon (Ploeg and Phillips 2001; Kim and Ferris 2002) and cucumber (Giné et al. 2014) but highest than for watermelon (37\%) (López-Gómez et al. 2014). Thus, the results of this study suggest that grafting cucumber onto RS 841 does not provide more tolerance to RKN, as it has been reported for watermelon grafted onto RS841 which suffered between $12 \%$ and $45 \%$ higher yield losses than the ungrafted cultivar at $P i<1$ and $P i$ around $70 \mathrm{~J}_{2} 250 \mathrm{~cm}^{-3}$ of soil, respectively (López-Gómez et al. 2016).

In relation to the ecophysiological status, both grafted and ungrafted cucumber showed reduced predawn water potential along with increases in $P i$, suggesting that increased levels of nematode population densities caused physiological drought (Audebert et al. 2000), probably as a result of impaired root functioning. Increased levels of nematode population also led to a decrease in chlorophyll content (as suggested by the negative relationship between $P i$ and the spectral based chlorophyll index $\mathrm{R}_{672} /\left[\mathrm{R}_{550}\right.$ $\left.\mathrm{x} \mathrm{R}_{708}\right]$ ). As a result, nematode-induced changes in both plant water and nutrient status led to a decrease in net photosynthetic rate. Therefore, in agreement with previous studies, nematode infection caused a reduction in leaf chlorophyll content (Audebert et al. 2000; Ahmed et al. 2009; Khan and Haque 2011; Giné et al. 2014; López-Gómez et al. 2015) as well as in photosynthetic activity (Loveys and Bird 1973; Melakeberhan et al. 1985) as suggested by the negative relationship between $P i$ and net photosynthetic rate. In addition, for both grafted or ungrafted cucumber plants, relative changes in yield were also related to the relative variation in both $\mathrm{R}_{672}$ / $\left[\mathrm{R}_{550} \times \mathrm{R}_{708}\right]$ and net photosynthetic rate, confirming previous results in which relative dry top weight of cucumber (Giné et al. 2014) or zucchinisquash biomass (López-Gómez et al. 2015) was related to relative leaf chlorophyll content. These results suggest that reflectance based chlorophyll indices might provide an estimation of the effects of $P i$ on photosynthetic capacity and their effects, thereof, on yield in situations in which RKN is the main biotic stressful agent.

There is little information on the effect of grafting cucurbits, in general, and cucumber, in particular, on Meloidogyne population dynamics and crop yield losses for a given agro-environmental area. This work provides new information on these parameters to aid growers to take decisions to manage RKN. In addition, the possibility of using the reflectance-based chlorophyll 
as an indicator of relative crop yield losses is pointed out although some more field studies are needed to be used for advisor purpose.

\section{Acknowledgments}

This work was partially funded by INIA project RTA2010-00017-C02 and FEDER support from the European Union and MINECO project AGL201349040-C2-1-R. Authors are thankful to Miriam Pocurull, Sheila Alcalá, Maria Julià and Miquel Massip for technical assistance in the field and laboratory work and Alba Valero for revision of the written English.

\section{References}

Agrios, G. N. (2005). Plant pathology. Elsevier academic press.

Ahmed, N., Abbasi, M. W., Shaukat, S. S., \& Zaki, M. J. (2009). Physiological changes in leaves of mungbean plants infected with Meloidogyne javanica. Phytopathologia Mediterranea, 48(2), 262-268.

Audebert, A., Coyne, D. L., Dingkuhn, M., \& Plowright, R. A. (2000). The influence of cyst nematodes (Heterodera sacchari) and drought on water relations and growth of upland rice in Côte d'Ivoire. Plant and Soil, 220(1-2), 235-242.

Barker, K. R., Shoemaker, P. B., \& Nelson, L. A. (1976). Relationships of initial population densities of Meloidogyne incognita and M. hapla to yield of tomato. Journal of Nematology, 8(3), 232-239.

Cansev, A., \& Ozgur, M. (2010). Grafting cucumber seedlings on Cucurbita spp.: comparison of different grafting methods, scions and their performance. Journal of Food Agriculture and Environment, 8, 804-809.

Cortada, L., Sorribas, F. J., Ornat, C., Kaloshian, I., \& Verdejo-Lucas, S. (2008). Variability in infection and reproduction of Meloidogyne javanica on tomato rootstocks with the Mi resistance gene. Plant Pathology, 57(6), 1125-1135.

Datt, B. (1998). Remote sensing of chlorophyll a, chlorophyll b, chlorophyll $\mathrm{a}+\mathrm{b}$, and total carotenoid content in eucalyptus leaves. 
Remote Sensing of Environment, 66(2), 111-121.

Davis, A. R., Perkins-Veazie, P., Sakata, Y., López-Galarza, S., Maroto, J. V., Lee, S. G., Huh, Y. C., Sun, Z., Miguel, A., King, S., Cohen, R., \& Lee, J. R. (2008). Cucurbit grafting. Critical Reviews in Plant Sciences, 27(1), 50-74.

Di Vito, M., \& Greco, N. (1988). The relationship between initial population densities of Meloidogyne artiellia and yield of winter and spring chickpea. Nematologia Mediterranea, 16, 163-166.

Edelstien, M. (2004). Grafting vegetables-crop plants: pros and cons. Acta Horticulture., 659, 235-237.

FAOSTAT (2016). Food and agriculture organization of the united nations statistics http://faostat.fao.org. Accessed 25 May 2016.

Ferris, H. (1985). Density-dependent nematode seasonal multiplication rates and overwinter survivorship: a critical point model. Journal of Nematology, 17(2), 93-100.

Giné, A., Carrasquilla, M., Martínez-Alonso, M., Gaju, N., \& Sorribas, F. J. (2016). Characterization of soil suppressiveness to root-knot nematodes in organic horticulture in plastic greenhouse. Frontiers in plant science, 7 .

Giné, A., López-Gómez, M., Vela, M. D., Ornat, C., Talavera, M., Verdejo-Lucas, S., \& Sorribas, F. J. (2014). Thermal requirements and population dynamics of root-knot nematodes on cucumber and yield losses under protected cultivation. Plant Pathology, 63(6), 1446-1453.

Gisbert, C., Sorribas, F. J., Martínez Perez, E. M., Gammoudi, N., Bernat, G., \& Picó, B. (2014). Grafting melons onto potential Cucumis spp. rootstocks. In 2nd Annual Conference COST Action FA1204Programme and Book of abstracts (pp. 57).

Goreta Ban, S., Dumičić, G., Raspudić, E., Vuletin Selak, G., \& Ban, D. (2014). Growth and yield of grafted cucumbers in soil infested with rootknot nematodes. Chilean journal of agricultural research, 74(1), 29-34. 
Guan, W., Zhao, X., Dickson, D. W., Mendes, M. L., \& Thies, J. (2014). Root-knot nematode resistance, yield, and fruit quality of specialty melons grafted onto Cucumis metulifer. Hortscience, 49(8), $1046-1051$.

Hussey, R. A., \& Barker, K. R. (1973). A comparison ofmethods of collecting inocula of Meloidogyne spp. including a new technique. Plant Disease Reporter, 57, 1025-1028.

Khan, M. R., \& Haque, Z. (2011). Soil application of Pseudomonas fluorescens and Trichoderma harzianum reduces root-knot nematode, Meloidogyne incognita, on tobacco. Phytopathologia Mediterranea, 50(2), 257-266.

Kim, D. G., \& Ferris, H. (2002). Relationship between crop losses and initial population densities of Meloidogyne arenaria in winter-grown oriental melon in Korea. Journal of Nematology, 34(1), 43-49.

King, S. R., Davis, A. R., Zhang, X., \& Crosby, K. (2010). Genetics, breeding and selection of rootstocks for Solanaceae and Cucurbitaceae. Scientia Horticulturae, 127(2), 106-111.

Kokalis-Burelle, N., Bausher, M. G., \& Rosskopf, E. N. (2009). Greenhouse evaluation of capsicum rootstocks for management of Meloidogyne incognita on grafted bell pepper. Nematropica, 39(1), 121132.

Kokalis-Burelle, N., \& Rosskopf, E. N. (2011). Microplot evaluation of rootstocks for control of Meloidogyne incognita on grafted tomato, muskmelon, and watermelon. Journal of Nematology, 43(3-4), 166-171.

Lee, J. M., Kubota, C., Tsao, S. J., Bie, Z., Echevarria, P. H., Morra, L., \& Oda, M. (2010). Current status of vegetable grafting: diffusion, grafting techniques, automation. Scientia Horticulturae, 127(2), 93-105.

Lee, J. M., \& Oda, M. (2010). Grafting of herbaceous vegetable and ornamental crops. Horticultural Reviews, 28, 61-124.

Liu, B., Ren, J., Zhang, Y., An, J., Chen, M., Chen, H., Xu, C., \& Ren, 
H. (2015). A new grafted rootstock against root-knot nematode for cucumber, melon, and watermelon. Agronomy for Sustainable Development, 35(1), 251-259.

López-Gómez, M., Giné, A., Vela, M. D., Ornat, C., Sorribas, F. J., Talavera, M., \& Verdejo-Lucas, S. (2014). Damage functions and thermal requirements of Meloidogyne javanica and Meloidogyne incognita on watermelon. Annals of Applied Biology, 165(3), 466-473.

López-Gómez, M., Flor-Peregrín, E., Talavera, M., Sorribas, F. J., \& Verdejo-Lucas, S. (2015). Population dynamics of Meloidogyne javanica and its relationship with the leaf chlorophyll content in zucchini. Crop Protection, 70, 8-14.

López-Gómez, M., Talavera, M., \& Verdejo-Lucas, S. (2016). Differential reproduction of Meloidogyne incognita and M. javanica in watermelon cultivars and cucurbit rootstocks. Plant Pathology, 65(1), $145-153$.

Loveys, B. R., \& Bird, A. F. (1973). The influence of nematodes on photosynthesis in tomato plants. Physiological Plant Pathology, 3(4), 525-529.

MAGRAMA (2013). Ministerio de Agricultura, Alimentación y Medio Ambiente, Anuario de estadística. Superficies y producciones de cultivos. http:/www.magrama.gob.es/es/estadistica/temas/ publicaciones/anuariode-estadistica/2012. Accessed 25 May 2016.

Maršić, N. K., \& Jakše, M. (2010). Growth and yield of grafted cucumber (Cucumis sativus L.) on different soilless substrates. Journal of Food, Agriculture \& Environment, 8(2), 654-658.

Melakeberhan, H. (2003). Physiological interactions between nematodes and their host plant. In Z. X. Chen, S. Y. Chen, \& D. W. Dickson (Eds.), Nematology advances and perspectives, nematode management and utilization (pp. 771-794). Wallingford: CAB International.

Melakeberhan, H., Brooked, R. C., Webster, J. M., \& d'Auria, J. M. (1985). The influence of Meloidogyne incognita on the growth, 
physiology and nutrient content of Phaseolus vulgaris. Physiological Plant Pathology, 26(3), 259-268.

Munera, M., Giné, A., Pocurull, M., Picó, B., Gisbert, C., \& Sorribas, F.J. (2014). Response of potential cucurbit rootstocks against Meloidogyne spp. In 2nd Annual Conference COST Action FA1204Programme and Book of abstracts (pp. 47).

Noling, J. W., \& Ferris, H. (1986). Influence of alfalfa plant growth on the multiplication rates and ceiling population density of Meloidogyne hapla. Journal of Nematology, 18(4), 505-511.

Ornat, C., Verdejo-Lucas, S., \& Sorribas, F. J. (1997). Effect of the previous crop on population densities of Meloidogyne javanica and yield of cucumber. Nematropica, 27, 85-90.

Oka, Y., Offenbach, R., \& Pivonia, S. (2004). Pepper rootstock graft compatibility and response to Meloidogyne javanica and M. incognita. Journal of Nematology, 36(2), 137-141.

Pavlou, G. C., Vakalounakis, D. J., \& Ligoxigakis, E. K. (2002). Control of root and stem rot of cucumber, caused by Fusarium oxysporum f. Sp. radicis-cucumerinum, by grafting onto resistant rootstocks. Plant Disease, 86(4), 379-338.

Picó, B., Esteras, C., Martinez, E., Munera, M., Giné, A., Sorribas, F.J., \& Gisbert, C. (2013) New Cucumis spp. resources for grafting melons. In 1st Annual Conference COST Action FA1204-Programme and Book of abstracts. (pp. 24).

Ploeg, A. T., \& Phillips, M. S. (2001). Damage to melon (Cucumis melo L.) cv. Durango by Meloidogyne incognita in southern California. Nematology, 3(2), 151-157.

Ros, C., Guerrero, M. M., Martiinez, M. A., Lacasa, A., \& Bello, A. (2006). Integrated management of Meloidogyne resistance in sweet pepper in greenhouses. IOBC WPRS BULLETIN, 29(4), 319.

Schomaker, C. H., \& Been, T. H. (2006). Distribution patterns and 
sampling. In R. N. Perry \& M. Moens (Eds.), Plant nematology (pp. 302-326). St. Albans: CAB International.

Seinhorst, J. W. (1965). The relation between nematode density and damage to plants. Nematologica, 11(1), 137-154.

Seinhorst, J. W. (1967). The relationship between population increase and population density in plant parasitic nematodes. III. Definition of terms host, host status and resistance. IV. The influence of external conditions on the regulation of population density. Nematologica, 13(1), 429-442.

Seinhorst, J. W. (1970). Dynamics of population of plant parasitic nematodes. Annual Review of Phytopathology, 8(1), 131-156.

Sigüenza, C., Schochow, M., Turini, T., \& Ploeg, A. (2005). Use of Cucumis metuliferus as a rootstock for melon to manage Meloidogyne incognita. Journal of Nematology, 37(3), 276-280.

Strajnar, P., Širca, S., Urek, G., Šircelj, H., Železnik, P., \& Vodnik, D. (2012). Effect of Meloidogyne ethiopica parasitism on water management and physiological stress in tomato. European Journal of Plant Pathology, 132(1), 49-57.

Talavera, M., Sayadi, S., Chirosa-Ríos, M., Salmerón, T., Flor-Peregrín, E., \& Verdejo-Lucas, S. (2012). Perception of the impact of root-knot nematode-induced diseases in horticultural protected crops of SouthEastern Spain. Nematology, 14(5), 517-527.

Talavera, M., Verdejo-Lucas, S., Ornat, C., Torres, J., Vela, M. D., Macias, F. J., Cortada, L., Arias, D. J., Valero, J., \& Sorribas, F. J. (2009). Crop rotations with $M i$ gene resistant and susceptible tomato cultivars for management of root-knot nematodes in plastic-houses. Crop Protection, 28(8), 662-667.

Thies, J. A., Ariss, J. J., Hassell, R. L., Levi, A., Sari, N., Solmaz, I., \& Aras, V. (2012). Resistant rootstocks for managing root-knot nematodes (Meloidogyne incognita) in grafted watermelon and melon. In Cucurbitaceae 2012. Proceedings of the Xth EUCARPIA Meeting on 
Genetics and Breeding of Cucurbitaceae. (pp. 202-211). University of Cukurova, Ziraat Fakultesi.

Thies, J. A., Ariss, J. J., Hassell, R. L., Olson, S., Kousik, C. S., \& Levi, A. (2010). Grafting for management of southern root-knot nematode, Meloidogyne incognita, in watermelon. Plant Disease, 94(10), 11951199.

Thies, J. A., Buckner, S., Horry, M., Hassell, R., \& Levi, A. (2015). Influence of Citrullus lanatus var. citroides rootstocks and their F1 hybrids on yield and response to root-knot nematode, Meloidogyne incognita, in grafted watermelon. Hortscience, 50(1), 9-12.

USDA (2015). Description of Commercial Cucurbit Rootstocks. “ http://www.vegetablegrafting.or/wp/wp-content/uploads/2015/02/usdascri-cucurbit-rootstock-table-feb-15.pdf" . Accessed 30 May 2016.

Vela, M. D., Giné, A., López-Gómez, M., Sorribas, F. J., Ornat, C., Verdejo-Lucas, S., \& Talavera, M. (2014). Thermal time requirements of root-knot nematodes on zucchini-squash and population dynamics with associated yield losses on spring and autumn cropping cycles. European Journal of Plant Pathology, 140(3), 481-490.

Verdejo-Lucas, S., Cortada, L., Sorribas, F. J., \& Ornat, C. (2009). Selection of virulent populations of Meloidogyne javanica by repeated cultivation of $M i$ resistance gene tomato rootstocks under field conditions. Plant Pathology, 58(5), 990-998.

Verdejo-Lucas, S., \& Sorribas, F. J. (2008). Resistance response of the tomato rootstock SC 6301 to Meloidogyne javanica in a plastic house. European Journal of Plant Pathology, 121(1), 103-107.

Whitehead, A. G., \& Hemming, J. R. (1965). A comparison of some quantitative methods of extracting small vermiform nematodes from soil. Annual of Applied Biology, 55(1), 25-38.

Zeck, W. (1971). Rating scheme for field evaluation of root-knot nematode infestations. Pflanzenschutz Nachrichten, 24, 141-144. 